\title{
The Morphometric Analysis of Crista Phallica in Identification of Sexes
}

\author{
El Análisis Morfométrico de Cresta Fálica en la Identificación de los Sexos
}

"Enis Ulucam; *"Banu Alicioglu; "Selman Cikmaz; "Ali Yilmaz \& ${ }^{* * *}$ Necdet Sut

ULUCAM, E.; ALICIOGLU, B.; CIKMAZ, S.; YILMAZ, A. \& SUT, N. The morphometric analysis of crista phallica in identification of sexes. Int. J. Morphol., 27(4):977-980, 2009.

SUMMARY: Crista phallica (CP) is used to determine sex in anthropology and criminal forensic medicine; however, it does not exist in anatomic and radiological terminology. The purpose of this retrospective study is morphometric analysis of the CP. We studied radiographs displaying several different clinical indications from patients whose bone maturation were fully complete. The crista phallica located on both sides of the medial portion of ischiopubic ramus (IPR) were localized and their peak points were determined. The distance from these peak points to the inner cortex of IPRs were measured, as well as the angles between the tangents passing the peak points from both sides. We determined the distance of the IPR (DIPR) for males and females sequentially as $21.3 \pm 3.5 \mathrm{~mm}$, and $17 \pm 2.8$ $\mathrm{mm}$, angle of $\mathrm{CP}(\mathrm{ACP})$ as $149.1^{\circ} \pm 15.7$, and $163.5^{\circ} \pm 13.4$. It was identified that ACP for females is less than ACP for males (p<0.001). $\mathrm{ACP}$ and DIPR alone are not sufficient criteria to determine sex. Therefore, the results of our findings show that it would be more useful to study other specifications and their metric analysis in order to determine sex.

KEY WORDS: Crista phallica; Anthropology; Hip bone; Morphometry; Human pelvis.

\section{INTRODUCTION}

The term $\mathrm{CP}$ is used in sex determination in anthropology and criminal forensic medicine, but it is not used in the anatomic and radiological terminology (Bruzek, 2002; Debona \& Mafart, 2006; FCAT, 1998). Crista phallica (phallic crest; CP) is defined as the hill where the cruses of the penis hold at the outer part of IPR (Fig.1). In women, the hip bone $\mathrm{CP}$ does not exist at the middle section of ramus or it is observed as a phallic bridge (similar to men but with a much narrower crest). That crest does not provide a distinguishable criterion to determine sex (Bruzek; Debona \& Mafart).

We arranged a study on radiograms of patients whom the sexes were predetermined, by conducting a morphometric analysis of $\mathrm{CP}$.

\section{MATERIAL AND METHOD}

We used pelvis images of 190 mature patients (77 men,
113 women) whose direct urinary system radiograms were taken at the Department of Radiology, Faculty of Medicine, Trakya University, Edirne, Turkey in 2008 because of several different clinical indications. Local ethics committee approved the procedure as well. All radiograms were studied by an experienced muscle-bone radiologist on a general purpose Polystar Siemens work station. We rejected the radiograms of patients with incomplete bone maturation, surgical procedures, acquired abnormalities and deformations at lumbosacral vertebrae. The CPs located on both sides of the medial part of IPRs were localized and their peak points were determined. The distances from the peak points to the inner cortexes of the IPRs (DIPR) were measured by electronic caliper in millimeters. The angle between tangents passing peak points from both sides were measured as angle of CP (ACP) (Fig. 2).

Statistical Analysis. Normality distribution of the variables (IPR and CP) was tested using a One-sample Kolmogorov Smirnov Test. Comparison of the variables between male and female was tested using Student's $t$ test due to the nor-

\footnotetext{
* MD, PhD, Department of Anatomy, Faculty of Medicine, Trakya University,

* MD, Department of Radiology, Faculty of Medicine,Trakya University, Turkey.

**** PhD, Department of Biostatistics, Faculty of Medicine, Trakya University, Turkey.
} 
mal distribution. And the right and left sides were tested by using paired $t$ tested. A $\mathrm{p}$ value $<0.05$ was considered as statistically significant. Statistica 7.0 (StatSoft Inc. Tulsa, OK, USA) software was used for statistical analysis.

Table I. Classification of crista phallica according to Bruzek's method. f: female form, i: intermediate form, m: male form.

\begin{tabular}{|c|}
\hline Crista phallica \\
\hline f lack of the crista phallica or presence of only little mound \\
\hline i intermediate form \\
\hline
\end{tabular}

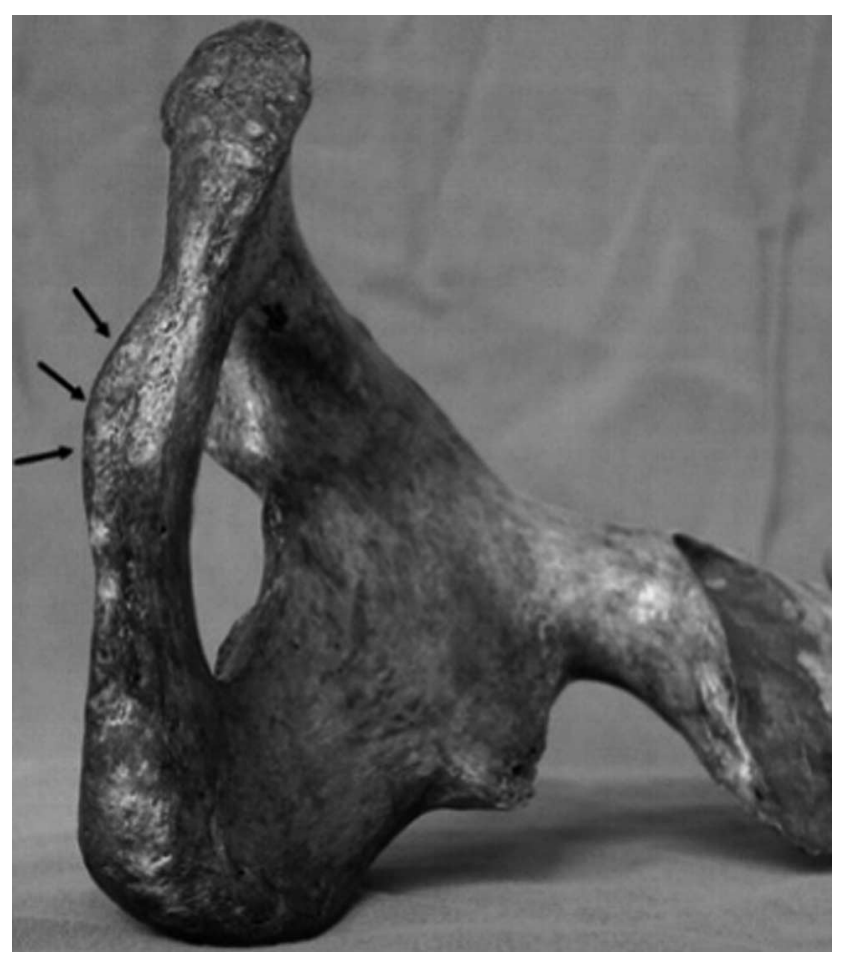

Fig. 1. Crista phallica; phallic crest (CP).

\section{RESULTS}

A total of 190 radiographic images were studied out of which 77 were males and 113 were females and the means and SD of ACP and DIPR are presented in Table II. The average DIPR for men as $21.3 \pm 3.5 \mathrm{~mm}$, and for women as

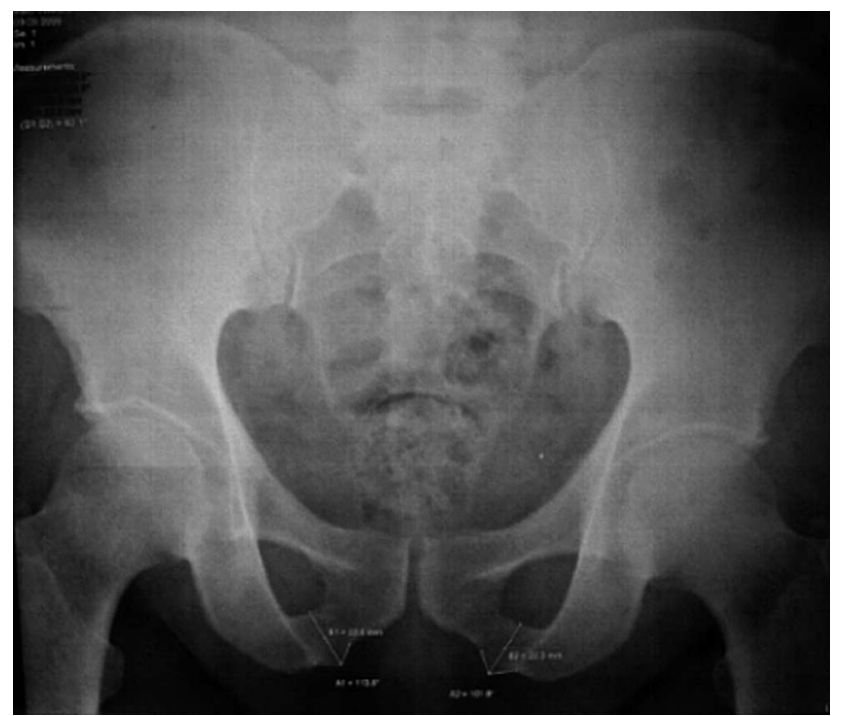

Fig. 2. Measurement technique of ACP and DIPR .

$17 \pm 2.8 \mathrm{~mm}$. The average degree of ACP as $149.1^{\circ} \pm 15.7$ for men, and $163.5^{\circ} \pm 13.4$ for women. The DIPR for men was statistically higher $(\mathrm{p}<0.001)$ than for women, and the ACP was higher in women $(\mathrm{p}<0.001)$ (Table II). The DIPR left side was higher than right side for women $(\mathrm{p}=0.026)$.

\section{DISCUSSION}

In the relevant literature, $\mathrm{CP}$ is used in observational methods of determination of sex (Bruzek; Debona \& Mafart; Dixit et al., 2007). We have not encountered any nformation in morphometric analysis of $\mathrm{CP}$ in literature.

When we searched the literature we found that long bones, skulls, and hip bones are often utilized for this purpose (Ferembach et al., 1980). It is known that not only sex affects the existence of morphological differences on bones, but also race, geographical location, age, and the bulk of muscles that hold the bones (Albanese, 2003; Coleman, 1969; Listi \& Bassett, 2006; Nagesh et al., 2007; Patriquin et al., 2002; Patriquin et al., 2005; Schulter-Ellis \& Hayek, 1988; Tague, 1989). For example; Schulter-Ellis and Hayek state in their studies that the acetabulum-pubis index among the

Table II. Analysis of radiographic ACP and DIPR measurements in mens and women. Results are presented means \pm SD. ACP: angle of crista phallica, DIPR: distance of ischiopubic ramus.

\begin{tabular}{lccccccccc}
\hline & \multicolumn{2}{c}{ Men (n:77) } & \multicolumn{2}{c}{ Women (n:113) } & \multicolumn{3}{c}{ Total (n:190) } \\
\cline { 2 - 9 } & right & left & $\boldsymbol{p}$ & right & left & $\boldsymbol{p}$ & men & women & $\boldsymbol{p}$ \\
\hline ACP $\left({ }^{\circ}\right)$ & $149.8 \pm 16.7$ & $148.4 \pm 14.7$ & 0.026 & $164.4 \pm 13.5$ & $162.6 \pm 13.3$ & 0.066 & $149.1 \pm 15.7$ & $163.5 \pm 13.4$ & $<0.001^{*}$ \\
DIPR(mm) & $21.4 \pm 3.5$ & $21.2 \pm 3.4$ & 0.475 & $16.8 \pm 2.8$ & $17.1 \pm 2.9$ & $0.026^{*}$ & $21.3 \pm 3.5$ & $17 \pm 2.8$ & $<0,001^{*}$ \\
\hline
\end{tabular}


population of South India is less than that of the populations of America and the Eskimos (Schulter-Ellis \& Hayek). Patriquin et al show in two studies conducted among people in South Africa that the white race has greater data by hip bone measurements than the black race (Patriquin et al., 2002; Patriquin et al., 2005).

The pelvis is the most accurate and reliable region of the skeleton for sex determination, and has shown accuracy rates approaching $95 \%$ or higher. In the literature, several methods have been developed to determine sex from the hip bone: Phenice's method, Iscan and Derrick's method, Ferembach et al. method, and Bruzek's method (Bruzek; Debona \& Mafart; Ferembach et al., 1980; Lovell, 1989; Phenice, 1969). Of these methods, Bruzek's method separates the hip bone into five characteristics (preauricular surface, greater sciatic notch, composite arch, inferior pelvis, ischiopubic proportion), and establishes three specifications (female, male, intermediate) for each of them according to sex. It is known that especially in the identification of male (m-m-m) and female (f-f-f) forms, this method gives $98 \%$ accuracy (Bruzek; Debona \& Mafart). According to Bruzek's method, three conditions must be considered at the same time when using ischiopubic ramus (IPR) at the hip bone in sex determination. The first condition is the external eversion of the bottom edge (female:f) or flat bottom edge (male:m) (Bruzek). The second is the strength ( $\mathrm{m}$ ) or weakness (f) of ramus, and the third is the crista phallica (Table I).

In his study, male morphology was determinated in $\% 70$ of Paris hip bone and $\% 51$ of Portugal hip bone. Female morphology was found in $\% 78$ and $\% 85$ respectively. Bruzek states that 5\% of female hip bones studied in Paris, and 3\% of female hip bones studied in Portugal fit the male morphology (Bruzek). In addition, two male hip bones studied in Portugal typically fit the female form. Bruzek's method better explains those criteria related to $\mathrm{CP}$ as subjective specifications through observations. Great importance is placed on the nature of the population studied and the experience of the researchers in distinguishing these specifications (Bruzek). Debona \& Mafart showed the CP on 228 hip bones in their attempt to prove the acceptability of Bruzek's method. They stated that 166 of them were male and 62 were female. Regarding the IPR in 228 bones, they identified 137 as being male and 91 as being female. No intermediate form was identified (Debona \& Mafart). In their study, they stress the difficulty of identifying the sex using Bruzek's method on the lower part of hip bone. Listi \& Bassett compared Bruzek's method with traditional methods in their study. They could not determine any meaningful differences for sex determination between these methods (Listi \& Bassett). Another method to determine sex from hip bones was developed by Phenice. In this method, three morphological specifications (ventral arch, subpubic concavity, medial aspect of the ischiopubic concavity) were used with $95 \%$ of true results in sex determination. CP was not used in this method (Lovell; Phenice).

In all these methods, no morphometric data was given. Through the observational methods, the researchers' knowledge, experience and deviations on the conclusions of the examples had a great impact on the results.

In the methods in which the morphometric analysis was used, a higher possibility existed that the results were more accurate since it was clearly shown where and how the measurements were made. One of the distinguishing aspects of our study was the identification of morphometric data for $\mathrm{CP}$. The other distinguishing aspect was the use of radiographs instead of the bones themselves. It is known that the radius of pelvis and subpubic angle are considered to be more accurate than radiograms when determining sex; however, it is difficult to determine these data in anthropology and forensic medicine for situations in which the bones or other parts are missing. As a consequence, we believe it is of the utmost importance to know the different specifications of pelvis bones of the sexes and determine their morphometric data.

ULUCAM, E.; ALICIOGLU, B.; CIKMAZ, S.; YILMAZ, A. \& SUT, N. El análisis morfométrico de cresta fálica en la identificación de los sexos. Int. J. Morphol., 27(4):977-980, 2009.

RESUMEN: La cresta fálica (Crista phallica, CP) se utiliza para determinación de sexo en antropología y la medicina forense, sin embargo, no existe en la terminología anatómica y radiológica. El objetivo de este estudio retrospectivo es el análisis morfométrico de la CP. Estudiamos radiografías que muestran varias indicaciones clínicas diferentes de pacientes cuya maduración ósea fue totalmente completa. La cresta fálica se situó a ambos lados de la porción medial de la rama isquio-pubiana (RIP), donde su localización y sus puntos más altos fueron determinados. La distancia desde estos puntos más altos a la corteza interna de la RIP fueron medidos, así como los ángulos entre las tangentes que pasaron por los puntos más altos de ambos lados. Se determinó la distancia de la RIP (DRIP) para hombres y mujeres de forma secuencial como $21,3 \pm 3,5 \mathrm{~mm}$, y $17 \pm 2,8 \mathrm{~mm}$, ángulo de la CP (ACP) como $149,1^{\circ} \pm 15,7$ y $163,5 \pm 13,4^{\circ}$. Se identificó que los ACP para mujeres fueron menores que las ACP para los hombres ( $\mathrm{p}<0,001)$. ACP y DRIP por sí solas no son criterios suficientes para determinar el sexo. Por lo tanto, los resultados de nuestros hallazgos muestran que sería más útil para estudiar otras especificaciones y sus análisis métricos a fin de determinar el sexo.

PALABRAS CLAVE: Cresta fálica; Antropología; Hueso de la cadera; Morfometría; Pelvis humana. 


\section{REFERENCES}

Albanese, J. A metric method for sex determination using the hip bone and the femur. J. Forensic Sci., 48:263-73, 2003.

Bruzek, J. A method for visual determination of sex, using the human hip bone. Am. J. Phys. Anthropol., 117:15768, 2002.

Coleman, W. H. Sex differences in the growth of the human bony pelvis. Am. J. Phys. Anthropol., 31:125-51, 1969.

Debona, L. \& Mafart, B. Sex determination fragmented hip bones using Bruzek method: experience in historic necropolis in provence (France). Anthropologie, 4(2):167-72, 2006.

Dixit, S. G.; Kakar, S.; Agarwal, S. \& Choudry, M. S. Sexing of human hip bones of Indian origin by dsicriminant function analysis. J. Forensic Leg. Med., 14:429-35, 2007.

Ferembach, D.; Schwidetzky, I. \& Stloukal, M. Recommendations for age and sex diagnoses of skeletons. J. Human Evol., 9:517-49, 1980.

FCAT. Terminologia Anatomica. New York, Thime Stuttgart, 1998. pp.11-2.

Listi, G. A. \& Bassett, H. E. Test of an alternative method for determining sex from the os coxae: applications for modern Americans. J. Forensic Sci., 51:248-52, 2006.

Lovell, N. C. Test of Phenice's technique for determining sex from the os pubis. Am. J. Phys. Anthropol., 79:11720, 1989.

Nagesh, K. R.; Kanchan, T. \& Bastia, B. K. Sexual dimorphism of acetabulum-pubis index in South-Indian population. Leg. Med. (Tokyo), 9:305-8, 2007.

Patriquin, M. L.; Steyn, M. \& Loth, S. R. Metric analysis of sex differences in South African black and white pelves. Forensic Sci. Int., 147:119-27, 2005.

Patriquin, M. L.; Steyn, M. \& Loth, S. R. Metric assessment of race from the pelvis in South Africans. Forensic Sci. Int., 127:104-13, 2002.

Phenice, T. W. A newly developed visual method of sexing the os pubis. Am. Phys. Anthropol., 30:297-301, 1969.
Schulter-Ellis, F. P. \& Hayek, L. A. Sexing North American Eskimo and Indian in nominate bones with the acetabulum/pubis index. J. Forensic Sci., 33:697-708, 1988.

Tague, R. G. Variation in pelvic size between males and females. Am. J. Phys. Anthropol., 80:59-71, 1989.

Correspondence to:

Enis Ulucam, MD, PhD.

Department of Anatomy, Trakya University

Faculty of Medicine, 22030

Edirne

TURKEY

Phone/fax: +902842355935

E-mail: eulucam@trakya.edu.tr

Received: 06-05-2009

Accepted: 22-08-2009 